\title{
Ischemic Brain Injury Leads to Brain Edema via Hyperthermia-Induced TRPV4 Activation
}

\author{
Yutaka Hoshi, ${ }^{1}$ Kohki Okabe, ${ }^{2,3}$ ㅈoji Shibasaki, ${ }^{4}$ Takashi Funatsu, ${ }^{2}$ Norio Matsuki, ${ }^{1}$ Y Yuji Ikegaya, ${ }^{1,5}$ \\ and ${ }^{\circ}$ Ryuta Koyama ${ }^{1}$ \\ ${ }^{1}$ Laboratory of Chemical Pharmacology, Graduate School of Pharmaceutical Sciences, University of Tokyo, Tokyo, 113-0033 Japan, ${ }^{2}$ Laboratory of \\ Bioanalytical Chemistry, Graduate School of Pharmaceutical Sciences, University of Tokyo, Tokyo, 113-0033 Japan, ${ }^{3}$ JST, PRESTO, Saitama, $332-0012$ \\ Japan, ${ }^{4}$ Department of Molecular and Cellular Neurobiology, Gunma University Graduate School of Medicine, Maebashi, 371-8514 Japan, and ${ }^{5}$ Center for \\ Information and Neural Networks, National Institute of Information and Communications Technology, Suita City, Osaka, 565-0871 Japan
}

Brain edema is characterized by an increase in net brain water content, which results in an increase in brain volume. Although brain edema is associated with a high fatality rate, the cellular and molecular processes of edema remain largely unclear. Here, we developed an in vitro model of ischemic stroke-induced edema in which male mouse brain slices were treated with oxygen-glucose deprivation (OGD) to mimic ischemia. We continuously measured the cross-sectional area of the brain slice for 150 min under macroscopic microscopy, finding that OGD induces swelling of brain slices. OGD-induced swelling was prevented by pharmacologically blocking or genetically knocking out the transient receptor potential vanilloid 4 (TRPV4), a member of the thermosensitive TRP channel family. Because TRPV4 is activated at around body temperature and its activation is enhanced by heating, we next elevated the temperature of the perfusate in the recording chamber, finding that hyperthermia induces swelling via TRPV4 activation. Furthermore, using the temperature-dependent fluorescence lifetime of a fluorescent-thermosensitive probe, we confirmed that OGD treatment increases the temperature of brain slices through the activation of glutamate receptors. Finally, we found that brain edema following traumatic brain injury was suppressed in TRPV4-deficient male mice in vivo. Thus, our study proposes a novel mechanism: hyperthermia activates TRPV4 and induces brain edema after ischemia.

Key words: brain edema; hyperthermia; ischemia; TRPV4

\section{Significance Statement}

Brain edema is characterized by an increase in net brain water content, which results in an increase in brain volume. Although brain edema is associated with a high fatality rate, the cellular and molecular processes of edema remain unclear. Here, we developed an in vitro model of ischemic stroke-induced edema in which mouse brain slices were treated with oxygen-glucose deprivation. Using this system, we showed that the increase in brain temperature and the following activation of the thermosensitive cation channel TRPV4 (transient receptor potential vanilloid 4) are involved in the pathology of edema. Finally, we confirmed that TRPV4 is involved in brain edema in vivo using TRPV4-deficient mice, concluding that hyperthermia activates TRPV4 and induces brain edema after ischemia.

\section{Introduction}

Brain edema is characterized by excessive water accumulation in the brain tissue or cells, resulting in an increase in brain volume

Received Oct. 6, 2017; revised April 26, 2018; accepted May 3, 2018.

Author contributions: N.M., Y.I., and R.K. designed research; Y.H., K.O., K.S., and T.F. performed research; Y.H., K.O., K.S., and R.K. analyzed data; Y.H. and R.K. wrote the paper.

This work was supported in part by Japan Society for the Promotion of Science Grant-in-Aid for Scientific Research (B) $17 \mathrm{H} 03988$ to R.K. and $15 \mathrm{H} 0300$ to K.S., Ministry of Education, Culture, Sports, Science and Technology Grant-inAid for Scientific Research on Innovation Area "Dynamic Regulation of Brain Function by Scrap \& Build System" 17 H05738 to R.K. and "Thermal Biology" 15 H05931 to K.O. and 15 H05934 to K.S., and the Brain Science Foundation to R.K.

The authors declare no competing financial interests.
(Klatzo, 1967). Brain edema is commonly associated with ischemic stroke with severe middle cerebral artery or hemispheric infarctions (Hacke et al., 1996; Aiyagari and Diringer, 2002). Because brain edema usually progresses at the early stage of ischemic stroke before ischemia-induced neuronal death and is associated with mortality rates reaching $55 \%$ with acute liver failure, $60 \%$ with traumatic brain injury (TBI), and $80 \%$ with isch-

Correspondence should be addressed to Dr. Ryuta Koyama, Laboratory of Chemical Pharmacology, Graduate School of Pharmaceutical Sciences, University of Tokyo, 7-3-1 Hongo, Bunkyo-ku, Tokyo 113-0033, Japan. E-mail: rkoyama@mol.f.u-tokyo.ac.jp.

DOI:10.1523/JNEUROSCI.2888-17.2018

Copyright $\odot 2018$ the authors $\quad 0270-6474 / 18 / 385700-10 \$ 15.00 / 0$ 
emic infarcts and intracerebral hemorrhage (Bernal et al., 2013; Stokum et al., 2016; Tucker et al., 2017), prompt antiedema intervention is necessary. Some studies have focused on antiedema therapies (Bardutzky and Schwab, 2007), but mostly, neuronal cell death (vs edema itself) has been targeted in stroke studies and drug discoveries. Thereby, effective neuroprotective treatment of brain edema has not been established, mainly because the cellular and molecular mechanisms underlying brain edema remain unclear.

To study ischemic stroke-induced brain edema, in vivo animal models have been used, in which the water content or infarct volume of isolated brain tissue is used as a parameter (Lin et al., 1993; Betz et al., 1994; Paczynski et al., 2000). To examine the cellular and molecular mechanisms underlying brain edema, however, the use of brain-targeted pharmacological experiments in vivo is difficult. Further, although it is essential to clarify the temporal development of brain edema, time-lapse analysis of edema in the same animal in vivo is not realistic. To overcome these issues for the study of brain edema, we have developed an in vitro model of ischemia-induced brain edema. The model enabled us to easily perform pharmacological experiments and to examine time-dependent brain swelling.

Using our in vitro model, we chose to study the involvement of hyperthermia (HT) in brain edema because hypothermiatargeted temperature management (HTTM) is sometimes effective for the treatment of severe TBI (Nielsen et al., 2013; Polderman and Varon, 2015). However, HTTM as a treatment for brain edema is not widely used because it is difficult to perform correctly. Additionally, it remains controversial whether HTTM is effective (Jiang et al., 2006; Hemmen et al., 2010) or not (Clifton et al., 2001, 2011) on brain injury, including edema, and the molecular targets of HTTM are unclear. In the present study, we specifically examined the role of thermosensitive transient receptor potential vanilloid 4 (TRPV4) in brain edema. TRPV4 is a nonselective cation channel that is expressed in the brain (Kauer and Gibson, 2009; Everaerts et al., 2010; White et al., 2016) and activated at around body temperature $\left(>27^{\circ} \mathrm{C}-34^{\circ} \mathrm{C}\right.$ ) (Güler et al., 2002; Shibasaki et al., 2007, 2015). TRPV4 also serves as an osmotic sensor that mediates changes in osmotic pressure in response to cellular responses in the brain (Liedtke and Friedman, 2003; Mizuno et al., 2003). Further, it has been suggested that TRPV4 activation mediates neuronal and glial responses to swelling in the retina (Ryskamp et al., 2014). In addition, the cellular volume of astrocytes is regulated by interactions between TRPV4 and the glial water channel aquaporin 4 (AQP4) (Benfenati et al., 2011; Jo et al., 2015). Further, some reports have studied the molecules that could regulate the downstream signaling of TRPV4, such as matrix metalloproteinases (Jie et al., 2015) or the expression of TRPV4, such as $\mathrm{Na}^{+} \mathrm{K}^{+} 2 \mathrm{Cl}^{-}$cotransporter (NKCC1) (Lu et al., 2017) in brain edema. However, it remains unclear whether and how TRPV4 is activated via temperaturedependent mechanisms in the process of brain edema. Here, we examined the possible involvement of HT following TRPV4 activation in brain edema in vitro and in vivo.

\section{Materials and Methods}

Animal ethics. Experiments were performed with the approval of the animal experiment ethics committee at the University of Tokyo (approval number: P24-70) and according to the University of Tokyo guidelines for the care and use of laboratory animals. C57BL/6J mice (male, 7-10 weeks old, SLC Japan, RRID:IMSR_JAX:000664) and TRPV4-deficient (TRPV4 knock-out [KO]) mice (Mizuno et al., 2003; Suzuki et al., 2003) were used. The genotypes were determined by PCR using the following steps: (1) DNA from a small toe sample was extracted; (2) the PCR product of $\sim 1500 \mathrm{bp}$ was amplified using a forward primer trp $v 4$ exon $4 \mathrm{R}$ (5'-TGTTCGGGGTGGTTTGGCCAGGATAT-3'), trpv4 neo forward: (5'-GCTGCATACGCTTGATCCGGCTAC-3') and a reverse primer trpv4 exon 4R (5'-GCTGAACCAAAGGACACTTGCATAG-3'). The deletion of $800 \mathrm{bp}$ was used to confirm the TRPV4 deficient. TRPV4deficient mice were mated to $\mathrm{C} 57 \mathrm{BL} / 6$ mice to the fourth generation, and we gained mutant line. We used the 25 th generation of TRPV4 KO mice, which had been backcrossed with C57BL/6J mice at every fifth generation. The mice were maintained under controlled temperatures and light schedule with unlimited food and water.

Composition of ACSF and $m A C S F$. ACSF contained the following: 127 mм NaCl, $26 \mathrm{~mm} \mathrm{NaHCO} 3,3.5 \mathrm{~mm} \mathrm{KCl,} 1.24 \mathrm{~mm} \mathrm{KH}_{2} \mathrm{PO}_{4}, 1.4 \mathrm{~mm}$ $\mathrm{MgSO}_{4}, 1.2 \mathrm{~mm} \mathrm{CaCl}_{2}$, and $10 \mathrm{~mm}$ glucose. Modified ACSF (mACSF) contained the following: $222.1 \mathrm{~mm}$ sucrose, $27 \mathrm{~mm} \mathrm{NaHCO}_{3}, 1.4 \mathrm{~mm}$ $\mathrm{NaH}_{2} \mathrm{PO}_{4}, 2.5 \mathrm{~mm} \mathrm{KCl}, 0.5 \mathrm{~mm}$ ascorbic acid, $1 \mathrm{~mm} \mathrm{CaCl}_{2}$, and $7 \mathrm{~mm}$ $\mathrm{MgSO}_{4}$. Both ACSF and mACSF were bubbled with $95 \% \mathrm{O}_{2}$ and $5 \% \mathrm{CO}_{2}$.

Slice preparation. The mice were decapitated under anesthesia, and the brains were immediately immersed in ice-cold ACSF. Coronal slices ( 400 $\mu \mathrm{m}$ thick) were prepared using a vibratome (VT1200S, Leica) in ice-cold $\mathrm{mACSF}$. Slices were maintained at room temperature in ACSF before time-lapse imaging. Both ACSF and mACSF were bubbled with $95 \% \mathrm{O}_{2}$ and $5 \% \mathrm{CO}_{2}$.

In vitro time-lapse imaging. Coronal slices were placed on membrane filters (Omnipore, Merck Millipore) in a recording chamber $(4 \mathrm{~cm} \times 1.5$ $\mathrm{cm} \times 3 \mathrm{~mm}$ ) and perfused with temperature-regulated ACSF at a rate of $5.0-5.5 \mathrm{ml} / \mathrm{min}$. The temperature of the ACSF was kept at $30 \pm 1.0^{\circ} \mathrm{C}$ and at $33 \pm 1.0^{\circ} \mathrm{C}$ for mild HT treatment and at $40 \pm 1.0^{\circ} \mathrm{C}$ for severe HT treatment using a hot plate (Thermo plate MATS-505SF, Tokai Hit) positioned under a recording chamber. The hot plate was used to keep the temperature of recording chamber (but not the slice itself) so that the perfusate in the chamber is not cooled down quickly. The perfusate was heated in an incubator, which was set out of the recording chamber and perfused into the recording chamber. We measured the temperature of perfusate in the chamber digitally in real time and confirmed that the temperature is kept at indicated value.

Brain slices were photographed every 30 min using a macrozoom microscope system, MVX-ZB10 (Olympus), equipped with a CCD camera, CSU-DV887-MCD (Yokogawa Electric). The area of the coronal slices was measured using ImageJ (National Institutes of Health, RRID: SCR_003070). For oxygen-glucose deprivation (OGD) treatment, bubbling of $95 \% \mathrm{O}_{2}$ and $5 \% \mathrm{CO}_{2}$ in ACSF was stopped and replaced with $95 \% \mathrm{~N}_{2}$ and $5 \% \mathrm{CO}_{2}$, and the glucose was replaced with sucrose to maintain the osmolality of ACSF (Salter and Fern, 2005; Thompson et al., 2006). After OGD treatment, the perfusate was promptly replaced with normal ACSF.

Water content measurement of brain slices. The extent of slice swelling was determined by the wet- and dry-weight method. The wet weight was determined immediately after imaging (140 min after OGD treatment). The dry weight was determined after drying the tissue to a constant weight at $55^{\circ} \mathrm{C}$ for $24 \mathrm{~h}$. Tissue water content was calculated as $\% \mathrm{H}_{2} \mathrm{O}=$ (wet weight - dry weight)/wet weight $\times 100 \%$.

Temperature imaging. Brain slices were labeled with a cell-permeable fluorescent polymeric thermometer (FPT, Funakoshi), and the intracellular temperature in brain slices was measured using fluorescence lifetime imaging microscopy (FLIM), as previously described with modification (Okabe et al., 2012; Hayashi et al., 2015).

Labeling of brain slices with a cell-permeable FPT. FPT stock solution ( $1 \%$ in water) was preincubated at $4^{\circ} \mathrm{C}$ overnight before use so that the polymer was swollen. Brain slices were incubated with $30 \mu \mathrm{l}$ of $0.08 \%$ FPT in 5\% glucose in water (Okabe et al., 2012; Hayashi et al., 2015) at room temperature for $10 \mathrm{~min}$. After incubation, FPT solution was removed, and the brain slices were rinsed with ACSF.

FLIM. For intracellular temperature imaging, the temperature of the microscope stage was regulated and monitored using INUBSF-ZILCS (Tokai Hit). A TCS-SP8 confocal laser-scanning microscope (Leica) equipped with a $470 \mathrm{~nm}$ laser (PDL $800-\mathrm{B}$, PicoQuant) and timecorrelated single photon counting (TCSPC) module Pico Harp 300 (PicoQuant) was used for fluorescence lifetime analysis. The pulse repe- 
tition rate of the $470 \mathrm{~nm}$ laser was set at $20 \mathrm{MHz}$. The fluorescence was captured with an HC PL APO $63 \times 1.40$ NA oil CS2 objective (Leica) with zoom factor of 1 in $128 \times 128$-pixel format and pinhole size of 5 unit at $100 \mathrm{~Hz}$ scanning speed (scanning duration was set for $30 \mathrm{~s}$ ) through a $500-700 \mathrm{~nm}$ bandpass filter. The laser power was controlled so that the photon count rate became $\sim 1 \%$ of pulse count rate $\left(2 \times 10^{7} \mathrm{~Hz}\right)$. The fluorescence lifetime images were obtained using SymPhoTime's "FAST FLIM" software (PicoQuant, RRID:SCR_016263). For quantitative analysis of lifetime, the obtained fluorescence decay curve was fitted with a double exponential function using SymPhoTime software (PicoQuant) using the following equation:

$$
I(t)=\mathrm{A}_{1} \exp \left(-t / \tau_{1}\right)+\mathrm{A}_{2} \exp \left(-t / \tau_{2}\right)
$$

Then, the fluorescence lifetime $\left(\tau_{\mathrm{f}}\right)$ was calculated using the following equation:

$$
\tau_{\mathrm{f}}=\left(\mathrm{A}_{1} \tau_{1}^{2}+\mathrm{A}_{2} \tau_{2}^{2}\right) /\left(\mathrm{A}_{1} \tau_{1}+\mathrm{A}_{2} \tau_{2}\right)
$$

The fluorescence lifetime for each pixel was calculated using Equation 2 and averaged within the whole image. The calibration curve for the temperature imaging of brain slices with the FPT was obtained by approximating the relationship between the averaged fluorescence lifetime of the FPT in brain slices and the temperature to the monomial (correlation coefficient $r=0.98$ ).

$$
\tau_{\mathrm{f}}(T)=0.4015 T-4.9746
$$

where $\mathrm{T}$ and $\tau_{\mathrm{f}}(\mathrm{T})$ represent the temperature $\left({ }^{\circ} \mathrm{C}\right)$ and the fluorescence lifetime (ns) at $\mathrm{T}^{\circ} \mathrm{C}$, respectively.

Cortical stab wound and histological analysis. Wild-type littermates or TRPV4 KO mice (10 weeks old) were anesthetized using ketamine (85 $\mathrm{mg} / \mathrm{kg}$ body weight) and xylazine ( $12 \mathrm{mg} / \mathrm{kg}$ body weight) via intraperitoneal injection and placed in a stereotactic instrument (Narishige SR$5 \mathrm{~V}-\mathrm{H})$. A 1-cm-long incision in the skin was made, and the skull was thinned (3-4 mm in length) in the right hemisphere region located $2 \mathrm{~mm}$ from the sagittal suture and $4 \mathrm{~mm}$ from the olfactory lobe by using an electric drill. We used a $26 \mathrm{G}$ needle to pierce the cortex $2 \mathrm{~mm}$ deep, 10 times at various angles using a stereotactic arm. Mice were monitored for $7 \mathrm{~d}$ and killed by perfusion with 4\% PFA. Brains were incubated overnight in $4 \%$ PFA and washed with PBS. The brains were incubated overnight in $25 \%$ sucrose/PBS and embedded in optimal cutting temperature (OCT) compound. Coronal brain sections ( $20 \mathrm{~mm}$ thickness) were made using a cryostat (Leica CM-3050S). Brain sections were stained with H\&E and mounted with mounting medium (CC mount). Images were acquired using an Olympus BX-53 microscope equipped with a cooled CCD camera (Olympus DP80). Images were analyzed by cellSens software (Olympus, RRID:SCR_014551), and cortical edema was measured as the increase in cortex thickness. To calculate the thickness of the cortex, 3 slices were selected across the injured zone (distance between slices: $40 \mu \mathrm{m})$ in each individual mouse.

Reagents. The selective TRPV4 antagonist HC-067047 (2-methyl-1[3-(4-morpholinyl)propyl]-5-phenyl-N-[3-(trifluoromethyl)phenyl]$1 \mathrm{H}$-pyrrole-3-carboxamide) and agonist GSK1016790A ([(N-((1S)-1$\{[4-((2 S)-2-\{[(2,4-$ dichlorophenyl)sulfonyl $]$ amino\}-3-hydroxypropanoyl)-1piperazinyl] carbonyl\}-3-methylbutyl)-1-benzothiophene-2-carboxamide]) and L-glutamic acid were purchased from Sigma-Aldrich. The selective NMDA antagonist D-AP5 and AMPA/kainate antagonist CNQX were purchased from Tocris Bioscience.

We used DMSO (final concentration, $0.05 \%$ in recording medium) as a vehicle for each reagent throughout the experiments. To make sure that DMSO alone does not affect the swelling of brain slice, we compared the swelling of slices (slice area) between naive control and DMSO, finding no significant differences at each time point (Control, $103.002 \pm 0.805 \%$; DMSO, $0.05 \%, 102.975 \pm 0.334 \% ; p=0.605$, two-way repeatedmeasures ANOVA; $n=8-10$ slices).

Immunostaining. After the time-lapse imaging, brain slices were fixed in $4 \%$ PFA at $4^{\circ} \mathrm{C}$ for $24 \mathrm{~h}$ and immunostained with the following primary antibodies: mouse anti-NeuN (1:500; Millipore catalog \#MAB377 RRID:AB_2298772), rabbit anti-GFAP (1:500; Millipore catalog \#AB5804 RRID:AB_2109645), and chicken anti-Iba1 (1:500; Abcam cat- alog \#ab139590 RRID:AB_2728648) and AlexaFluor-488-, AlexaFluor594-, and AlexaFluor-647-conjugated secondary antibodies (1:500; Thermo Fisher Scientific, catalog \#A-11039 RRID:AB_2534096, catalog \#A-11005 RRID:AB_2534073, catalog \#A-21244 RRID:AB_2535812, respectively). The fixed slices were rinsed three times with $0.1 \mathrm{M}$ phosphate buffer. Slices were then permeabilized $72 \mathrm{~h}$ at $4^{\circ} \mathrm{C}$ in $0.1 \mathrm{M}$ phosphate with $0.1 \%$ Triton X-100 and $10 \%$ goat serum. After permeabilization, the samples were subsequently incubated with primary antibodies in $0.1 \mathrm{M}$ phosphate buffer with $0.1 \%$ Triton X-100 and $10 \%$ goat serum overnight at room temperature with agitation. After primary antibody incubation, the slices were rinsed three times with $0.1 \mathrm{~m}$ phosphate buffer and then incubated with secondary antibodies in $0.1 \mathrm{M}$ phosphate buffer with $0.1 \%$ Triton X-100 and 10\% goat serum overnight at room temperature with agitation. Finally, the samples were rinsed three times with $0.1 \mathrm{M}$ phosphate buffer, and images were obtained with a confocal microscope FV1200 (Olympus, RRID:SCR_016264). The stacked images were prepared using ImageJ. Z-series images were collected at $1.0 \mu \mathrm{m}$ steps and analyzed using ImageJ.

Measurement of propidium iodide-positive cell. Brains were removed and cut at $400 \mu \mathrm{m}$ thickness by vibratome and incubated $150 \mathrm{~min}$ with propidium iodide $(0.1 \mathrm{mg} / \mathrm{L})$. After incubation, brain slices were observed under confocal microscope FV1200 (Olympus) with a $40 \times$ objective without fixing. The stacked images were prepared using ImageJ. $Z$-series images were collected at $0.33 \mu \mathrm{m}$ steps, and $16 Z$-sections $(5.0$ $\mu \mathrm{m}$ thick) were stacked using ImageJ. We counted propidium iodidepositive cell and calculated the density of propidium iodide-positive cells (cells $/ \mathrm{mm}^{2}$ ).

Experimental design and statistical analysis. Prism 6 (RRID: SCR_002798) and Sigma-Plot 12 (RRID:SCR_003210) software were used to analyze data and generate the graphs in this work. Minimum sample sizes were estimated from previously published datasets with similar experimental parameters. Data were pooled from at least 3 independent experiments. Data were collected and statistically analyzed in a blind manner to avoid bias. For water content measurements, we used 3 slices from each mouse $(n=4)$. For area and temperature measurements, we used 2 slices (randomly assigned to either the treatment or control group) from each mouse (at least $n=3$ per experiment). For in vivo experiments, we measured thickness of cortex from 3 points per mice $(n=5)$ (for sample sizes and $p$ values, see figure legends). The data are represented as mean \pm SEM. The Mann-Whitney $U$ test was used for nonparametric statistics, whereas the Student's $t$ test or Tukey's test after two-way repeated-measures ANOVA was used for parametric statistics.

\section{Results \\ TRPV4 inhibition supresses OGD-induced brain edema in vitro}

To examine brain edema in vitro, we performed time-lapse analysis of the changes in the area of acutely sectioned brain slices in ACSF. We placed coronal slices of adult mouse brains in a recording chamber that was perfused with warmed $\left(30 \pm 1.0^{\circ} \mathrm{C}\right) \mathrm{ACSF}$ (Fig. 1A). To mimic ischemia, the brain slices were treated with OGD, which is frequently used to induce an ischemic condition in vitro (Salter and Fern, 2005; Thompson et al., 2006), for the first $10 \mathrm{~min}$ of the $150 \mathrm{~min}$ recording session. We set the recording session for $150 \mathrm{~min}$ because we found that the swelling of slices reaches plateau at $\sim 150 \mathrm{~min}$ in our in vitro model of brain edema. To detect swelling of brain slices, we first measured the water contents of the tissue, which provides a general index of brain edema (Lin et al., 1993; Betz et al., 1994; Paczynski et al., 2000). We found a significant increase in water content in the OGD group after $150 \min \left(t_{(22)}=7.515, p<0.001\right.$; Fig. $\left.1 B\right)$. To confirm the swelling of brain slices, changes in the cross-sectional area were continuously monitored for 150 min under macroscopic microscopy. We found that OGD treatment induced swelling of brain slices (Fig. $1 A$ ) and significantly increased the area of slices at $150 \mathrm{~min}\left(F_{(2,75)}=7.313, p<0.001\right.$; Fig. $\left.1 C\right)$. 
A

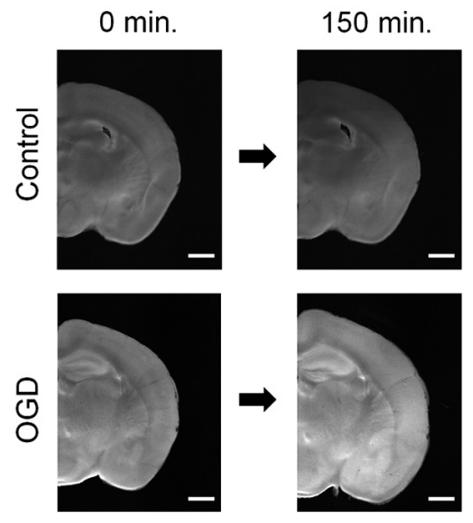

C

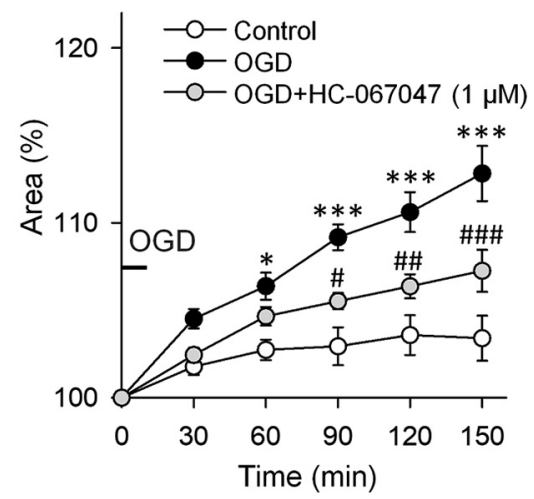

B

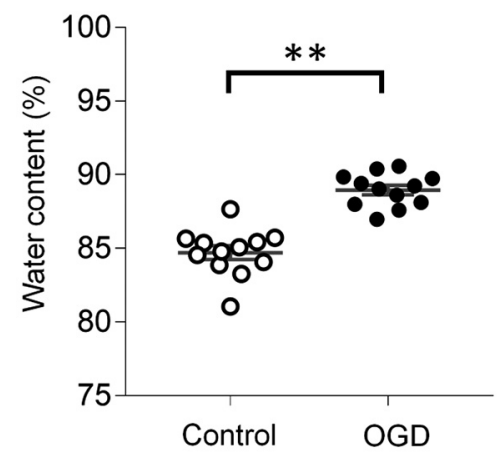

D

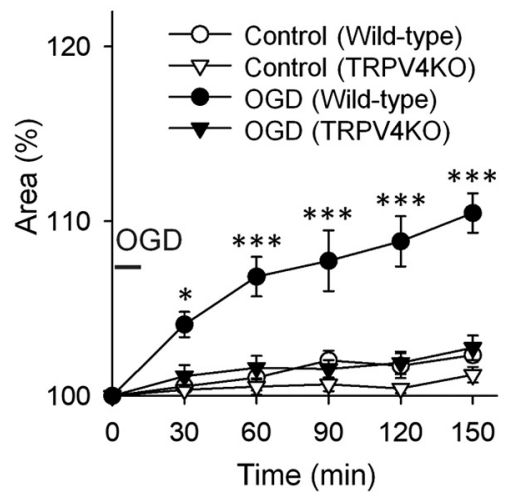

Figure 1. OGD-induced brain edema is suppressed by TRPV4 inhibition in vitro. $\boldsymbol{A}$, Representative images of control and OGD-treated brain slices in the recording chamber under macroscopic microscopy at 0 and $150 \mathrm{~min}$. Scale bars, $1 \mathrm{~mm}$. B, The water content of brain slices at $150 \mathrm{~min}$. The water content was calculated as $\% \mathrm{H}_{2} \mathrm{O}=$ (wet weight - dry weight) $/$ wet weight $\times 100 \%$. The water content of OGD-treated slices was significantly higher than that of the control. ${ }^{* *} p<0.01$ (Student's $t$ test). $n=12$ slices from 4 mice. $C$, The percentage changes in the area of brain slices compared with 0 min are shown. $0 \mathrm{GD}$ was applied between 0 and $10 \mathrm{~min}$. The TRPV4 antagonist HC-067047 (1 $\mu \mathrm{M})$ was applied from 0 to $150 \mathrm{~min}$. The OGD-induced increase in the area of the brain slices was suppressed by HC-067047. ${ }^{*} p<0.05$ (Tukey's test after two-way repeated-measures AN0VA). ${ }^{* * *} p<0.001$ versus control (Tukey's test after two-way repeated-measures ANOVA). " $p<0.05$ (Tukey's test after two-way repeated-measures

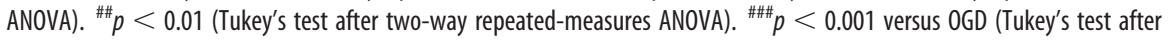
two-way repeated-measures ANOVA). $n=4-9$ slices from 4 to 9 mice. $D$, Brain slices prepared from wild-type littermate or TRPV4 KO mice were subjected to OGD treatment. In the TRPV4 KO group, the increase in the area of the brain slice was suppressed compared with wild-type littermate. ${ }^{*} p<0.05$ versus control (wild-type) (Tukey's test after two-way repeated-measures ANOVA). ${ }^{* * *} p<0.001$ versus control (wild-type) (Tukey's test after two-way repeated-measures ANOVA). $n=3-6$ slices from 3 to 6 mice. Data are mean \pm SEM.

Using the in vitro system, we examined the involvement of the thermosensitive TRPV4 receptor in OGD-induced swelling of brain slices. The potent and selective TRPV4 antagonist HC-067047 suppressed the OGD-induced increase of slice area $\left(F_{(2,75)}=\right.$ 7.313, $p<0.001$; Fig. $1 C$ ). Further, the OGD treatment did not increase the area of brain slices that were prepared from TRPV4 $\mathrm{KO}$ mice $\left(F_{(3,65)}=9.258, p<0.001\right.$; Fig. $\left.1 D\right)$. These results indicate that activation of TRPV4 is a key pathway in the process of OGD-induced slice swelling.

TRPV4 activation induces brain edema in vitro

Next, we directly examined the effect of HT. HT was applied by maintaining the temperature of ACSF at $33 \pm 1.0^{\circ} \mathrm{C}$ (mild HT) or at $40 \pm 1.0^{\circ} \mathrm{C}$ (severe HT) from 0 to $150 \min \left(F_{(2,45)}=3.455, p<\right.$ 0.001 ; Fig. 2A). HT treatment significantly increased the area of brain slices, which was blocked by the TRPV4 antagonist HC$067047\left(F_{(2,45)}=3.455, p<0.001\right.$; Fig. $\left.2 A\right)$, indicating that activation of TRPV4 is involved in the process of HT-induced slice swelling. Further, HT did not increase the area of brain slices prepared from TRPV4 $\mathrm{KO}$ mice $\left(F_{(2,45)}=\right.$ $0.496, p=0.625$; Fig. $2 B)$. We also confirmed that there was statistically no significant difference in the density of propidium iodide-positive dead cells between control, OGD, and severe HT treatment (Control, $847.413 \pm 81.917$ cells $/ \mathrm{mm}^{2} ;$ OGD $995.793 \pm 88.759$ cells $/ \mathrm{mm}^{2}$; severe HT, $934.792 \pm 85.505$ cells $/ \mathrm{mm}^{2} ; F_{(2,17)}, p=$ 0.484; one-way ANOVA, $n=6$ slices from 3 mice).

Because TRPV4 activation was required for both OGD- (Fig. 1C,D) and HT-induced (Fig. $2 A, B$ ) increases of slice area, the potent and selective TRPV 4 agonist GSK1016790A was applied from 0 to $150 \mathrm{~min}$ to examine the sufficiency of TRPV4 activation to produce brain tissue swelling. We found that GSK1016790A increased the area of brain slices in a dosedependent manner $\left(F_{(2,45)}=3.455, p=\right.$ 0.002; Fig. 2C). In addition, GSK1016790A did not increase the area of brain slices that were prepared from TRPV4 KO mice (Fig. 2B). These results indicate that TRPV4 activation is sufficient to induce brain edema in vitro.

\section{OGD treatment increases the} temperature of brain slices through glutamate receptor activation

Our findings suggest that brain temperature is elevated after ischemia, which results in sensitization of TRPV4 receptors, followed by brain edema. Thus, we next examined whether cellular temperatures in the brain slices are elevated after OGD treatment. For this purpose, we performed intracellular temperature mapping using an FPT, a thermosensitive fluorescence compound that diffuses throughout the cell (Okabe et al., 2012; Hayashi et al., 2015). The brain slices were labeled with FPT, and the temperature-dependent fluorescence lifetime of FPT was measured using TCSPC system-based FLIM (Okabe et al., 2012; Hayashi et al., 2015). We found that layer 1 of the parietal association cortex in brain slices (Fig. $3 A$ ) is efficiently labeled with FPT (Fig. 3B). To confirm that the fluorescence lifetime of FPT is positively correlated with the elevation of temperature, we elevated the ACSF temperature in a recording chamber, finding that the fluorescence lifetime of FPT is positively correlated with the elevation of ACSF temperature (Fig. 3C).

Next, we investigated whether OGD treatment affects intracellular temperature in brain slices. We found that OGD treatment prolonged the fluorescence lifetime of FPT in layer 1 of the parietal association cortex (Fig. 4A), indicating that the intracellular temperature in brain slices increased after OGD. We then calculated the estimated temperature $\left({ }^{\circ} \mathrm{C}\right)$ of the brain slices, using a regression line that plots the relationship between temperature and the fluorescence lifetime of FPT (Fig. 3C). The average difference in the estimated intracellular temperatures between the control and OGD group was $2.12^{\circ} \mathrm{C}(U=88, p=0.004$; Fig. $4 B)$. 
A

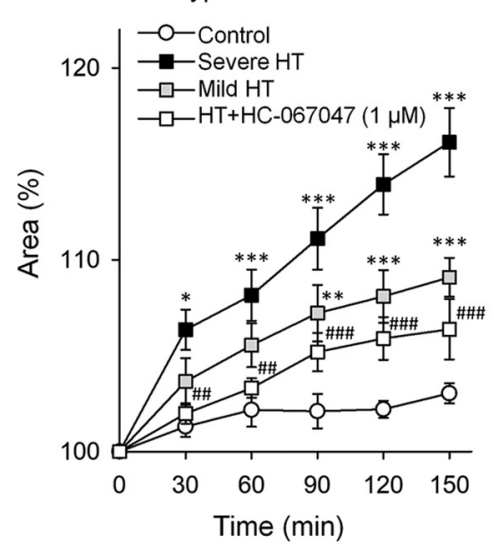

B

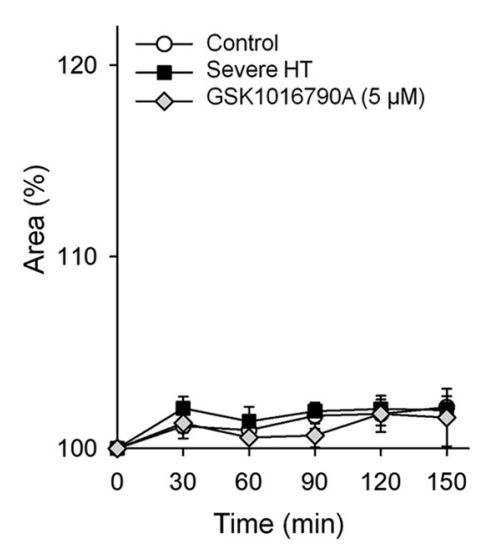

C

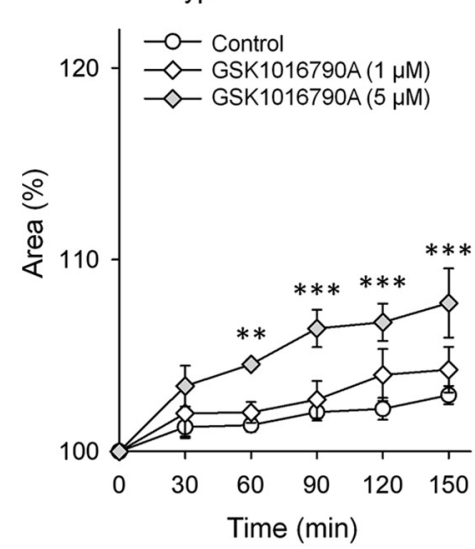

Figure 2. TRPV4 activation causes brain edema in vitro. $A$, The temperature of the ACSF was kept at $30 \pm 1.0^{\circ} \mathrm{C}$ and at $33 \pm 1.0^{\circ} \mathrm{C}$ for mild $\mathrm{HT}$ treatment and at $40 \pm 1.0^{\circ} \mathrm{C}$ for severe $\mathrm{HT}$ treatment. HT treatment significantly increases the area of brain slices, a phenomenon blocked by the TRPV4 antagonist HC-067047. ${ }^{*} p<0.05$ (Tukey's test after two-way repeated-measures ANOVA). ${ }^{* *} p<$

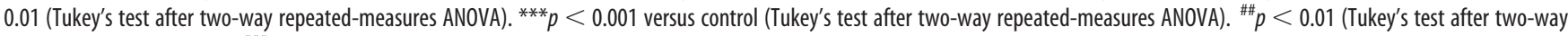
repeated-measures ANOVA). ${ }^{\# \#} p<0.001$ versus severe HT (Tukey's test after two-way repeated-measures ANOVA). $n=4$ slices from 4 mice. $B$, Brain slices prepared from TRPV4 K0 mice were subjected to treatment with HT or the TRPV4 agonist GSK1016790A. There were no significant differences between each group in the increase in the area of brain slices. $n=3-5$ slices from 3 to 5 mice. C, Brain slices prepared from wild-type mice were treated with different concentrations of GSK1016790A. There was a dose dependency in the increase of brain slice area. ${ }^{* *} p<0.01$ (Tukey's test after two-way repeated-measures ANOVA). ${ }^{* * *} p<0.001$ (Tukey's test after two-way repeated-measures ANOVA). $n=3-6$ slices from 3 to 6 mice. Data are mean \pm SEM.

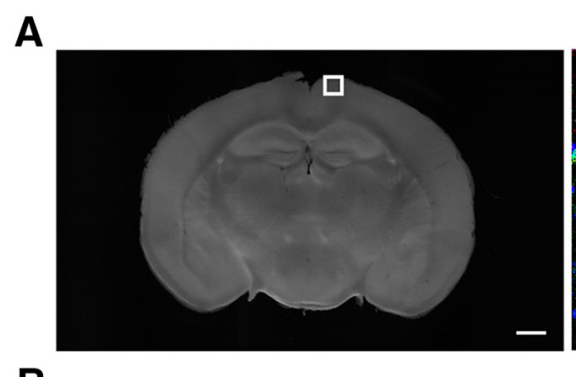

B

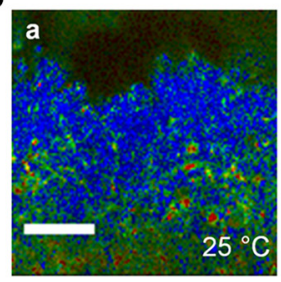

GFAP lba1 NeuN
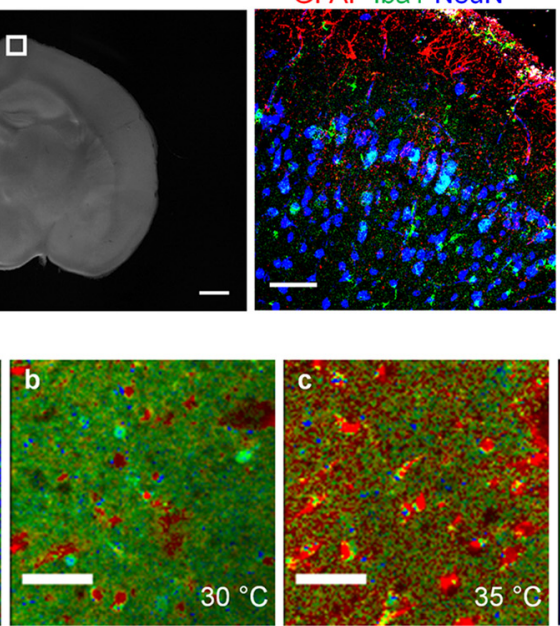

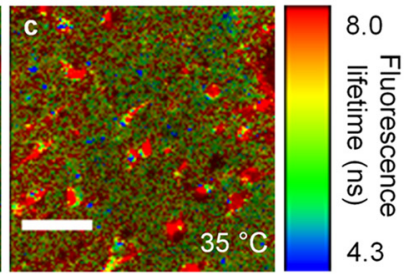

C

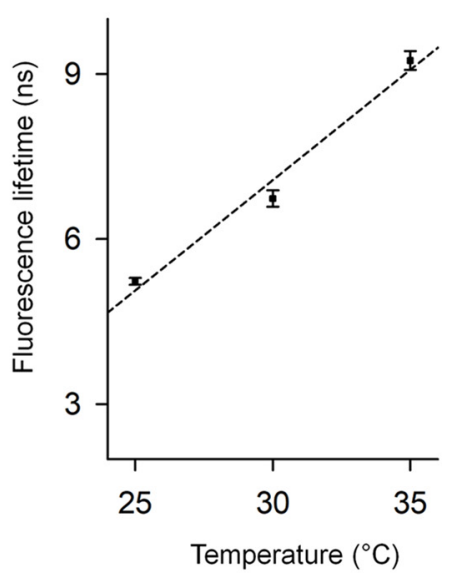

Figure 3. Analysis of the intracellular temperature of the cortex in brain slices. $A$, Left, Representative transparent image of the cross-sectional brain slice. Scale bar, $1 \mathrm{~mm}$. Right, Magnified image of the squared area in $\boldsymbol{A}$ immunostained for the astrocytic marker GFAP, microglial marker Iba1, and neuronal marker NeuN. Scale bars, $50 \mu$ m. $\boldsymbol{B}$, Fluorescence lifetime images of the cell-permeable FPT in brain slices at each temperature of the perfusate: $B \boldsymbol{a}, 25^{\circ} \mathbf{C} ; \boldsymbol{B b}, 30^{\circ} \boldsymbol{C} ; \boldsymbol{B C}, 35^{\circ} \mathrm{C}$. The images were taken $3 \mathrm{~h}$ after the slices were placed in the recording chamber. Scale bar, $50 \mu \mathrm{m}$. $\boldsymbol{C}, \mathrm{The}$ calibration line of the temperature of the perfusate and the fluorescence lifetime of FPT in brain slices ( $n=2$ or 3 areas for each temperature).

Because OGD is associated with the release of glutamate into the extracellular space and with the depolarized membrane potentials through activation of glutamate receptors and TRPV4 (Lipski et al., 2006), we investigated whether glutamate and its receptor activation mediate OGD-induced increase in the estimated intracellular temperature and the area of the brain slice. By observing the cellular temperature with FPT, we found that OGD-induced increase in the temperature was suppressed by pharmacologically blocking the glutamate receptors by coapplication of the selective NMDA receptor antagonist, D-AP5 (50 $\mu \mathrm{M})$ and the non-NMDA receptor antagonist, CNQX $(50 \mu \mathrm{M})$ $\left(F_{(2,45)}=16.973, p<0.001\right.$; Fig. $\left.4 C\right)$. We also found that OGDinduced increase in the area of brain slices was blocked by coapplication of D-AP5 and CNQX $\left(F_{(2,40)}=5.437, p<0.001\right.$; Fig. $4 D$ ). Furthermore, we found that the glutamate application alone resulted in the increase in the estimated temperature $\left(t_{(25)}=\right.$ $2.135, p=0.0427$; Fig. $4 E)$ and the area of brain slices $\left(F_{(1,30)}=\right.$ 3.151, $p=0.021$; Fig. $4 F)$. These results suggest that OGDinduced glutamate release and following activation of the glutamate receptors are upstream of the increase in temperature of brain slices. Together with the results that HT induces the swelling of brain slices via TRPV4 activation (Fig. 2), we propose a novel mechanism: ischemia-induced glutamatergic signaling results in the increase in brain temperature and the brain edema via TRPV4 activation.

\section{Brain edema is attenuated in TRPV4 $\mathrm{KO}$ mice in vivo}

Finally, we investigated the role of TRPV4 in brain edema in vivo using a mouse model of TBI, which is induced by the stab wound injury (Dwyer et al., 1996; Schwab et al., 2001; Wang et al., 2007; 
A
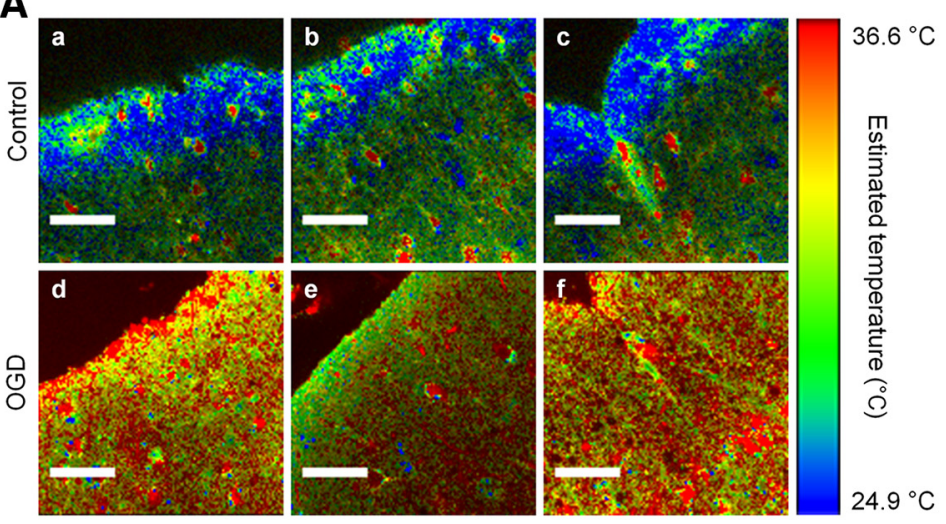

B

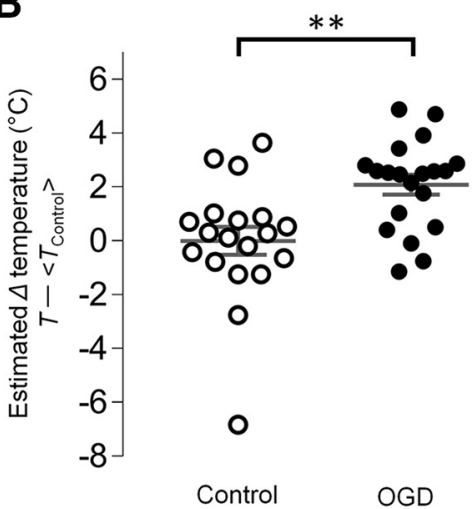

C

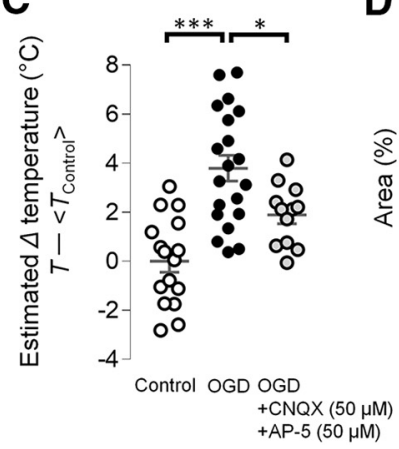

D

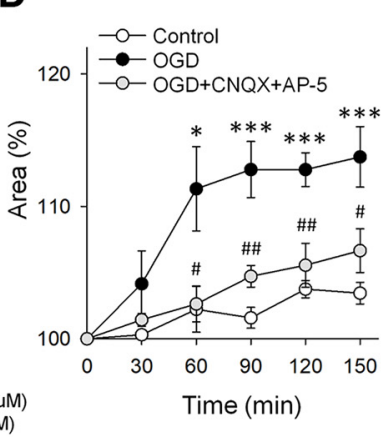

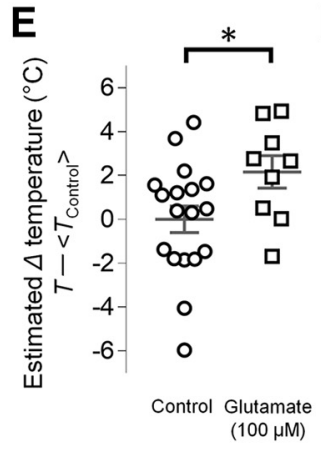

$\mathbf{F}$

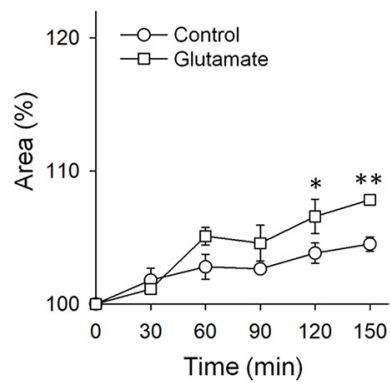

Figure 4. The OGD treatment raises the intracellular temperature of brain slices via glutamatergic signaling. $\boldsymbol{A}$, Representative images of control (Aa-Ac) and OGD-treated (Ad-Af) brain slices when the temperature of the perfusate was set at $30^{\circ} \mathrm{C}$. The images were taken within $3 \mathrm{~h}$ after the slices were placed in the recording chamber. Scale bars, $50 \mu \mathrm{m}$. $\boldsymbol{B}$, The temperature estimated by fluorescence lifetime of FPT was shown as difference between the temperature of each sample and the average of temperatures of control samples (estimated $\Delta$ temperature, i.e., $T-<T_{\text {control }}>$ ). The estimated $\Delta$ temperature was significantly higher in the $0 \mathrm{GD}$ group compared with control. The average difference of calculated intracellular temperature was $2.12^{\circ} \mathrm{C}$. ${ }^{* *} p<0.01$ (MannWhitney $U$ test). $n=18-20$ areas from 3 mice. C, The $0 G D$ treatment significantly increased the estimated temperature of brain slices, a phenomenon blocked by coapplying the glutamate receptor

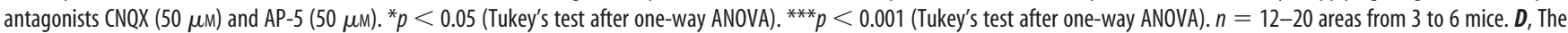
OGD-induced increase in the area of the brain slices was blocked by coapplying CNQX (50 $\mu \mathrm{M})$ and AP-5 (50 $\mu \mathrm{M}) .{ }^{*} p<0.05$ versus control (Tukey's test after two-way repeated-measures ANOVA). ${ }^{* * *} p<0.001$ versus control (Tukey's test after two-way repeated-measures ANOVA). ${ }^{\#}<0.05$ versus 0 GD (Tukey's test after two-way repeated-measures ANOVA). ${ }^{\# \#} p<0.01$ versus 0 GD (Tukey's test after two-way repeated-measures ANOVA). $n=3$ or 4 slices. $\boldsymbol{E}$, When glutamate $(100 \mu \mathrm{M})$ was applied in the recording chamber and the FPT images were taken $3 \mathrm{~h} \mathrm{later,} \mathrm{the} \mathrm{estimated}$ $\Delta$ temperature was significantly higher in the glutamate group compared with control. ${ }^{*} p<0.05$ (Student's test). $n=9-18$ areas from 3 mice. $\boldsymbol{F}$, The glutamate treatment (100 $\mu \mathrm{M}$ ) significantly increased the area of brain slices. ${ }^{*} p<0.05$ versus control (Tukey's test after two-way repeated-measures ANOVA). ${ }^{* *} p<0.01$ versus control (Tukey's test after two-way repeated-measures ANOVA). $n=4$ slices from 4 mice.

Belkacemi et al., 2017) because TBI often induces brain ischemia, which is followed by brain edema (Bouma et al., 1991; Coles, 2004; Donkin and Vink, 2010; Pascual et al., 2011; Veenith et al., 2016; Khan et al., 2017).

To perform TBI, defined cortical stab wounds were applied to the brains of wild-type and TRPV4 KO mice. Seven days after the lesions, the injured areas were analyzed in $\mathrm{H} \& \mathrm{E}$-stained sections under light microscopy (Fig. 5A, arrowheads). Cortical edema on the lesion side was relatively quantified with respect to the contralateral side and presented as the percentage of increase in the injured cortex thickness (Fig. 5B). We found that formation of edema is significantly suppressed in TRPV4 KO mice compared with wild-type littermate $\left(t_{(8)}=3.292, p=0.011\right.$; Fig. $\left.5 B\right)$. These results strongly indicate that TRPV4 activation is also a key determinant of brain edema development in vivo and demonstrate that our in vitro model is consistent with the development of edema in vivo.

\section{Discussion}

In the present study, using in vitro and in vivo models of brain edema, we found that TRPV4 activation is involved in the process of brain edema. Further, using intracellular temperature imaging with an FPT, we found that ischemic conditions increase the temperature of brain slices, which leads to swelling of brain slices.
A
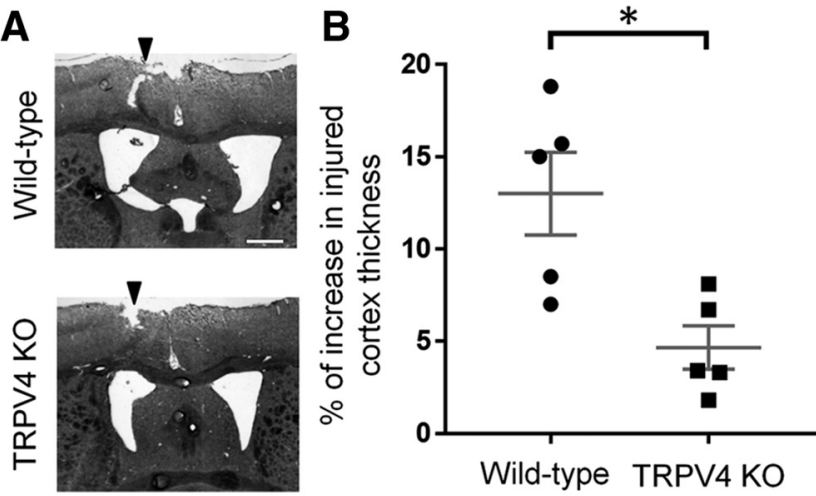

Figure 5. Brain edema after brain injury is suppressed in TRPV4 KO mice in vivo. $\boldsymbol{A}$ Representative transparent images of the cortical area of H\&E-stained brain slices after cortical stab wound injury in wild-type littermate and TRPV4 KO mice (bottom). Arrowheads indicate the lesion sites. Scale bar, $1 \mathrm{~mm}$. $\boldsymbol{B}$, The percentage increase in injured cortical thickness $7 \mathrm{~d}$ after cortical stab wound injury in the wild-type and TRPV4 KO mice. The injured cortex thickness is significantly lower in TRPV4 KO mice than in WT mice. ${ }^{*} p<0.05$ (Student's $t$ test). $n=5$ mice. 
Thus, our results suggest the possible involvement of HTinduced TRPV4 activation in brain edema after ischemic stroke. Although HTTM has not been widely used as a treatment for brain edema because its mechanisms remain unclear, our results may provide TRPV4 as a molecular target of HTTM in the prevention of brain edema. This idea is partly supported by our in vivo data showing that TBI-induced brain edema is suppressed in TRPV4 KO mice.

Our in vitro model of brain edema enabled us to precisely and stably manipulate the experimental conditions surrounding brain tissue, including the temperature of the recording media and the concentration of applied reagents. Furthermore, the coronal area of the slices, an index of brain edema, can be measured without additional damage to the brain tissue, allowing us to record time-dependent developments of brain edema. Brain edema was characterized as cytotoxic, vasogenic, or ionic (Klatzo, 1967; Stokum et al., 2016): cytotoxic edema is caused by water movement into the intracellular compartment of brain cells, whereas vasogenic and ionic edema is caused by water movement from the vasculature into interstitial areas of the brain. The water movement is caused by the disruption of blood-brain barrier, which is vasogenic edema-specific, or by ion extravasation mediated by plasma membrane channels and transporters. Thus, our in vitro model of brain edema partially represents cytotoxic edema because there is no contribution of blood flow in acute brain slices.

We confirmed the involvement of TRPV4 in brain edema in vivo using a mouse model of TBI, which was induced by stab wound injury (Belkacemi et al., 2017). We used the TBI model instead of ischemia models, such as middle cerebral artery occlusion because whether brain edema is induced in rodent models of ischemia remains controversial: some studies reported that edema was not observed (Hirayama et al., 2015; Jie et al., 2015), but others observed edema at least to some extent (Manley et al., 2000; Shen et al., 2018). These controversial points were of concern for histologically assessing edema in the present study. Thus, we used the TBI model because brain edema was reproducible and able to be assessed histologically (Fig. 5) as previously reported (Belkacemi et al., 2017). Even though TBI is not an ischemia model, we have found that TRPV4 is involved in brain edema also in vivo, confirming that the findings obtained in our novel in vitro model are not in vitro artifacts. However, because TBI is not an ischemia model, future studies with clinical and in vivo experimental analyses are necessary to determine whether TRPV4 is involved in brain edema under ischemic conditions.

Our results suggest that TRPV4 activation is a key determinant in the induction of brain edema after ischemia-induced HT in vitro. In addition, TRPV4 activation is sufficient to induce brain edema in vitro, as the TRPV4 agonist GSK1014790A alone induced swelling of brain slices. The effect of GSK1014790A on the swelling of brain slices was dose-dependent. In addition, the effect of HT on the swelling of brain slices was temperaturedependent, which is in consistent with the property of TRPV4 that fever additively activates TRPV4 in response to an increase in temperature (Shibasaki et al., 2007). These findings suggest that stronger and additive activation of TRPV4 accelerates the development of brain edema.

Recently, it has been reported that TRPV4 mediates brain edema (Jie et al., 2015; Lu et al., 2017), but whether and how the thermosensitivity of TRPV4 contribute to brain edema has been unknown. TRPV4 is a nonselective cation channel through which $\mathrm{Ca}^{2+}$ enters the cell from the extracellular space in both neurons and astrocytes (Ryskamp et al., 2014; Shibasaki et al., 2014; Rakers et al., 2017). Because the elevation in intracellular $\mathrm{Ca}^{2+}$ levels is critical for the formation of brain edema (Abe et al., 1988), $\mathrm{Ca}^{2+}$ influx through TRPV4 may directly contribute to the pathogenesis of brain edema. Furthermore, it has been shown that TRPV4 activation induces water transport through Ano1, a $\mathrm{Ca}^{2+}$-activated $\mathrm{Cl}^{-}$channel (Takayama et al., 2014). Therefore, it is highly possible that OGD-induced TRPV4 activation causes $\mathrm{Ca}^{2+}$ influx, and this leads to water transport through $\mathrm{Ca}^{2+}$ activated channels. Alternatively, the influx of other cations through TRPV4 may also contribute to brain edema. For example, neuronal swelling is partly caused by prolonged increases in intracellular $\mathrm{Na}^{+}$that result in osmotic imbalances and water entry (Rungta et al., 2015). Additionally, TRPV4 could produce edema by serving as an osmotic sensor that mediates changes in osmotic pressure (Liedtke and Friedman, 2003; Mizuno et al., 2003) or by being activated by membrane stretch (Mochizuki et al., 2009; Shibasaki, 2016). Therefore, it is possible that swelling itself recurrently activates TRPV4 to exacerbate brain edema.

We investigated the temperature of brain slices using FPT and a TCSPC system-based FLIM, finding that OGD treatment, which mimics ischemia, increased the temperature of brain slices by an estimated elevation of $2.12^{\circ} \mathrm{C}$ on average. Further, we found that mild HT (estimated increase of $1.0^{\circ} \mathrm{C}$ to $5.0^{\circ} \mathrm{C}$ ) could result in the swelling of slices. TRPV4 activation is enhanced by heating (Shibasaki, 2016) and additively activated in response to an increase in temperature (Shibasaki et al., 2007). Therefore, heatevoked $\left(\sim 2^{\circ} \mathrm{C}\right)$ TRPV4 sensitization in specific temperatureelevated regions may further progress the development of brain edema through an additive TRPV4 activation. Moreover, this activation of TRPV4 can possibly be accelerated via mechanical stimuli that is caused by the cell swelling itself because TRPV4 also serves as a volume-sensitive mechanosensor (Nilius et al., 2001). In addition, we have previously reported that the TRPV4 activation enhanced NMDA receptor activation (Shibasaki et al., 2007). Therefore, TRPV4 activation might be involved in multiple steps, such as an enhancement of NMDA receptor activation, $\mathrm{Ca}^{2+}$ influx by HT-induced activation, resulting in the dysregulation of cell volume changes in the process of brain edema. It has been shown that $2^{\circ} \mathrm{C}-3^{\circ} \mathrm{C}$ changes in brain temperature significantly affect brain functions and neuronal properties (Hodgkin and Katz, 1949; Ritchie and Straub, 1957; Schiff and Somjen, 1985; Moser and Andersen, 1994). The mechanisms by which ischemic conditions increase the intracellular temperature of brain cells remain to be elucidated. Practically all processes in the body could be temperature-sensitive, although to different extents.

In our in vitro model, there is no contribution of blood vessels and cerebral blood flow to the increase of temperature. Promoted transcription of immediate early genes in ischemia (Honkaniemi and Sharp, 1996) could cause the increase of temperature, as gene transcription is potentially accompanied by heat production. Furthermore, ischemia-induced apoptotic processes could be another candidate mechanism that mediates the increase in temperature because apoptosis results in heat production via DNA cleavage (Gota et al., 2009). Ischemia-induced expression of pyrogenic cytokine (Hill et al., 1999) may also be a cause for heat production because pyrogenic cytokines cause thermal responses in the body, resulting in temperature increase (Evans et al., 2015). However, it should be noted that 
pyrogenic cytokines presumably act on the hypothalamus in vivo, and thus they would not explain the temperature rise in the brain slices in vitro.

Several molecules other than TRPV4 have also been suggested to be involved in the pathogenesis of brain edema. Such molecules include reactive oxygen species, AQP4, vascular endothelial growth factor, inflammatory cytokines, and plasma membrane ion channels and transporters (Manley et al., 2000; Adeva et al., 2012; Jie et al., 2015; Lu et al., 2017). Whether activated TRPV4 interacts with these molecules to induce brain edema should be studied in the future.

Although we have not determined TRPV4 of what cells are most responsible for edema, it is predictable that astrocytes play considerable roles because the water channel AQP4 is highly expressed in astrocytic endfeet (Tait et al., 2008) and forms complexes with TRPV4 in astrocytes (Benfenati et al., 2011). It should also be noted that TRPV4 is expressed in a restricted subpopulation of astrocytes (Shibasaki et al., 2014), which may result in the differences in temperature elevation between each astrocyte. In addition, the TBI model used in the present study was shown to be associated with astrocyte proliferation (Belkacemi et al., 2017) and reactive astrocytes (Heinrich et al., 2014). Notably, it is reported that ischemia significantly increased the number of TRPV4-positive astrocytes and contributed to the $\mathrm{Ca}^{2+}$ influx in reactive astrocytes (Butenko et al., 2012). It is also reported that initiation of cell swelling caused membrane stretch and produced arachidonic acids and their metabolites. These molecules activate TRPV4 and Kir4.1 channels in the Müller glia, which is similar to astrocytes (Jo et al., 2015). The activation of Kir4.1 can cause $\mathrm{K}^{+}$ buffering, and this ion influx can generate the driving force of water influx via AQP4.

There are multiple forms of AQP4 expressed in the brain, such as M1 and M23 isoforms (Tait et al., 2008). It has been shown that M1 exhibits higher water permeability than M23 (Fenton et al., 2010). In addition, these isoforms have opposing effects on intramembrane organization of AQP4 (Furman et al., 2003), which may affect the efficiency of AQP4 anchoring to intracellular proteins and the localization of AQP4 in a cell. Thus, it is possible that multiple AQP4 isoforms contribute differently to the generation and prevention of brain edema, but how these isoforms interact with TRPV4 in the process of edema remains unknown.

It should also be noted that there are endogenous mechanisms that prevent astrocytic swelling via activation of adrenergic receptors (Vardjan et al., 2016). Thus, it is possible that the release of noradrenaline in our in vitro system is impaired, allowing the swelling of brain slices.

Brain edema usually progresses from the early stage of ischemic stroke. Thus, antiedema intervention would be effective to prevent the following neuronal death. In our in vitro model, significant swelling of brain slices was observed as early as $30 \mathrm{~min}$ after the onset of OGD, allowing us to study the early phases of changes in the brain milieu after ischemia. Thus, our in vitro model will be useful to discover molecules in addition to TRPV4 that are essential for antiedema therapies.

\section{References}

Abe K, Kogure K, Watanabe T (1988) Prevention of ischemic and postischemic brain edema by a novel calcium antagonist (PN200-110). J Cereb Blood Flow Metab 8:436-439. CrossRef Medline

Adeva MM, Souto G, Donapetry C, Portals M, Rodriguez A, Lamas D (2012) Brain edema in diseases of different etiology. Neurochem Int 61:166-174. CrossRef Medline
Aiyagari V, Diringer MN (2002) Management of large hemispheric strokes in the neurological intensive care unit. Neurologist 8:152-162. Medline

Bardutzky J, Schwab S (2007) Antiedema therapy in ischemic stroke. Stroke 38:3084-3094. CrossRef Medline

Belkacemi T, Niermann A, Hofmann L, Wissenbach U, Birnbaumer L, Leidinger P, Backes C, Meese E, Keller A, Bai X, Scheller A, Kirchhoff F, Philipp SE, Weissgerber P, Flockerzi V, Beck A (2017) TRPC1- and TRPC3-dependent $\mathrm{Ca}^{2+}$ signaling in mouse cortical astrocytes affects injury-evoked astrogliosis in vivo. Glia 65:1535-1549. CrossRef Medline

Benfenati V, Caprini M, Dovizio M, Mylonakou MN, Ferroni S, Ottersen OP, Amiry-Moghaddam M (2011) An aquaporin-4/transient receptor potential vanilloid 4 (AQP4/TRPV4) complex is essential for cell-volume control in astrocytes. Proc Natl Acad Sci U S A 108:2563-2568. CrossRef Medline

Bernal W, Hyyrylainen A, Gera A, Audimoolam VK, McPhail MJ, Auzinger G, Rela M, Heaton N, O'Grady JG, Wendon J, Williams R (2013) Lessons from look-back in acute liver failure? A single centre experience of 3300 patients. J Hepatol 59:74-80. CrossRef Medline

Betz AL, Keep RF, Beer ME, Ren XD (1994) Blood-brain barrier permeability and brain concentration of sodium, potassium, and chloride during focal ischemia. J Cereb Blood Flow Metab 14:29-37. CrossRef Medline

Bouma GJ, Muizelaar JP, Choi SC, Newlon PG, Young HF (1991) Cerebral circulation and metabolism after severe traumatic brain injury: the elusive role of ischemia. J Neurosurg 75:685-693. CrossRef Medline

Butenko O, Dzamba D, Benesova J, Honsa P, Benfenati V, Rusnakova V, Ferroni S, Anderova M (2012) The increased activity of TRPV4 channel in the astrocytes of the adult rat hippocampus after cerebral hypoxia/ ischemia. PLoS One 7:e39959. CrossRef Medline

Clifton GL, Miller ER, Choi SC, Levin HS, McCauley S, Smith KR Jr, Muizelaar JP, Wagner FC Jr, Marion DW, Luerssen TG, Chesnut RM, Schwartz M (2001) Lack of effect of induction of hypothermia after acute brain injury. N Engl J Med 344:556-563. CrossRef Medline

Clifton GL, Valadka A, Zygun D, Coffey CS, Drever P, Fourwinds S, Janis LS, Wilde E, Taylor P, Harshman K, Conley A, Puccio A, Levin HS, McCauley SR, Bucholz RD, Smith KR, Schmidt JH, Scott JN, Yonas H, Okonkwo DO (2011) Very early hypothermia induction in patients with severe brain injury (the National Acute Brain Injury Study: Hypothermia II): a randomised trial. Lancet Neurol 10:131-139. CrossRef Medline

Coles JP (2004) Regional ischemia after head injury. Curr Opin Crit Care 10:120-125. CrossRef Medline

Donkin JJ, Vink R (2010) Mechanisms of cerebral edema in traumatic brain injury: therapeutic developments. Curr Opin Neurol 23:293-299. CrossRef Medline

Dwyer BE, Nishimura RN, Lu SY, Alcaraz A (1996) Transient induction of heme oxygenase after cortical stab wound injury. Brain Res Mol Brain Res 38:251-259. CrossRef Medline

Evans SS, Repasky EA, Fisher DT (2015) Fever and the thermal regulation of immunity: the immune system feels the heat. Nat Rev Immunol 15:335349. CrossRef Medline

Everaerts W, Nilius B, Owsianik G (2010) The vanilloid transient receptor potential channel TRPV4: from structure to disease. Prog Biophys Mol Biol 103:2-17. CrossRef Medline

Fenton RA, Moeller HB, Zelenina M, Snaebjornsson MT, Holen T, MacAulay N (2010) Differential water permeability and regulation of three aquaporin 4 isoforms. Cell Mol Life Sci 67:829-840. CrossRef Medline

Furman CS, Gorelick-Feldman DA, Davidson KG, Yasumura T, Neely JD, Agre P, Rash JE (2003) Aquaporin-4 square array assembly: opposing actions of M1 and M23 isoforms. Proc Natl Acad Sci U S A 100:1360913614. CrossRef Medline

Gota C, Okabe K, Funatsu T, Harada Y, Uchiyama S (2009) Hydrophilic fluorescent nanogel thermometer for intracellular thermometry. J Am Chem Soc 131:2766-2767. CrossRef Medline

Güler AD, Lee H, Iida T, Shimizu I, Tominaga M, Caterina M (2002) Heatevoked activation of the ion channel, TRPV4. J Neurosci 22:6408-6414. CrossRef Medline

Hacke W, Schwab S, Horn M, Spranger M, De Georgia M, von Kummer R (1996) 'Malignant' middle cerebral artery territory infarction: clinical course and prognostic signs. Arch Neurol 53:309-315. CrossRef Medline

Hayashi T, Fukuda N, Uchiyama S, Inada N (2015) A cell-permeable FPT for intracellular temperature mapping in mammalian cell lines. PLoS One 10:e117677. CrossRef Medline 
Heinrich C, Bergami M, Gascón S, Lepier A, Viganò F, Dimou L, Sutor B, Berninger B, Götz M (2014) Sox2-mediated conversion of NG2 glia into induced neurons in the injured adult cerebral cortex. Stem Cell Rep 3:1000-1014. CrossRef Medline

Hemmen TM, Raman R, Guluma KZ, Meyer BC, Gomes JA, Cruz-Flores S, Wijman CA, Rapp KS, Grotta JC, Lyden PD (2010) Intravenous thrombolysis plus hypothermia for acute treatment of ischemic stroke (ICTuSL): final results. Stroke 41:2265-2270. CrossRef Medline

Hill JK, Gunion-Rinker L, Kulhanek D, Lessov N, Kim S, Clark WM, Dixon MP, Nishi R, Stenzel-Poore MP, Eckenstein FP (1999) Temporal modulation of cytokine expression following focal cerebral ischemia in mice. Brain Res 820:45-54. CrossRef Medline

Hirayama Y, Ikeda-Matsuo Y, Notomi S, Enaida H, Kinouchi H, Koizumi S (2015) Astrocyte-mediated ischemic tolerance. J Neurosci 35:37943805. CrossRef Medline

Hodgkin AL, Katz B (1949) The effect of sodium ions on the electrical activity of the giant axon of the squid. J Physiol 108:37-77. CrossRef Medline

Honkaniemi J, Sharp FR (1996) Global ischemia induces immediate-early genes encoding zinc finger transcription factors. J Cereb Blood Flow Metab 16:557-565. CrossRef Medline

Jiang JY, Xu W, Li WP, Gao GY, Bao YH, Liang YM, Luo QZ (2006) Effect of long-term mild hypothermia or short-term mild hypothermia on outcome of patients with severe traumatic brain injury. J Cereb Blood Flow Metab 26:771-776. CrossRef Medline

Jie P, Tian Y, Hong Z, Li L, Zhou L, Chen L, Chen L (2015) Blockage of transient receptor potential vanilloid 4 inhibits brain edema in middle cerebral artery occlusion mice. Front Cell Neurosci 9:141. CrossRef Medline

Jo AO, Ryskamp DA, Phuong TT, Verkman AS, Yarishkin O, MacAulay N, Križaj D (2015) TRPV4 and AQP4 channels synergistically regulate cell volume and calcium homeostasis in retinal müller glia. J Neurosci 35: 13525-13537. CrossRef Medline

Kauer JA, Gibson HE (2009) Hot flash: TRPV channels in the brain. Trends Neurosci 32:215-224. CrossRef Medline

Khan M, Khan H, Singh I, Singh AK (2017) Hypoxia inducible factor-1 alpha stabilization for regenerative therapy in traumatic brain injury. Neural Regen Res 12:696-701. CrossRef Medline

Klatzo I (1967) Presidental address: neuropathological aspects of brain edema. J Neuropathol Exp Neurol 26:1-14. CrossRef Medline

Liedtke W, Friedman JM (2003) Abnormal osmotic regulation in trpv4 ${ }^{-1-}$ mice. Proc Natl Acad Sci U S A 100:13698-13703. CrossRef Medline

Lin TN, He YY, Wu G, Khan M, Hsu CY (1993) Effect of brain edema on infarct volume in a focal cerebral ischemia model in rats. Stroke 24:117121. CrossRef Medline

Lipski J, Park TI, Li D, Lee SC, Trevarton AJ, Chung KK, Freestone PS, Bai JZ (2006) Involvement of TRP-like channels in the acute ischemic response of hippocampal CA1 neurons in brain slices. Brain Res 1077:187-199. CrossRef Medline

Lu KT, Huang TC, Tsai YH, Yang YL (2017) Transient receptor potential vanilloid type 4 channels mediate na-K-cl-co-transporter-induced brain edema after traumatic brain injury. J Neurochem 140:718-727. CrossRef Medline

Manley GT, Fujimura M, Ma T, Noshita N, Filiz F, Bollen AW, Chan P, Verkman AS (2000) Aquaporin-4 deletion in mice reduces brain edema after acute water intoxication and ischemic stroke. Nat Med 6:159-163. CrossRef Medline

Mizuno A, Matsumoto N, Imai M, Suzuki M (2003) Impaired osmotic sensation in mice lacking TRPV4. Am J Physiol Cell Physiol 285:C96-C101. CrossRef Medline

Mochizuki T, Sokabe T, Araki I, Fujishita K, Shibasaki K, Uchida K, Naruse K, Koizumi S, Takeda M, Tominaga M (2009) The TRPV4 cation channel mediates stretch-evoked $\mathrm{Ca}^{2+}$ influx and ATP release in primary urothelial cell cultures. J Biol Chem 284:21257-21264. CrossRef Medline

Moser EI, Andersen P (1994) Conserved spatial learning in cooled rats in spite of slowing of dentate field potentials. J Neurosci 14:4458-4466. CrossRef Medline

Nielsen N, Wetterslev J, Cronberg T, Erlinge D, Gasche Y, Hassager C, Horn J, Hovdenes J, Kjaergaard J, Kuiper M, Pellis T, Stammet P, Wanscher M, Wise MP, Åneman A, Al-Subaie N, Boesgaard S, Bro-Jeppesen J, Brunetti I, Bugge JF, et al. (2013) Targeted temperature management at $33^{\circ} \mathrm{C}$ versus $36^{\circ} \mathrm{C}$ after cardiac arrest. N Engl J Med 369:2197-2206. CrossRef Medline

Nilius B, Prenen J, Wissenbach U, Bödding M, Droogmans G (2001) Differential activation of the volume-sensitive cation channel TRP12 (OTRPC4) and volume-regulated anion currents in HEK-293 cells. Pflugers Arch 443:227-233. CrossRef Medline

Okabe K, Inada N, Gota C, Harada Y, Funatsu T, Uchiyama S (2012) Intracellular temperature mapping with a fluorescent polymeric thermometer and fluorescence lifetime imaging microscopy. Nat Commun 3:705. CrossRef Medline

Paczynski RP, Venkatesan R, Diringer MN, He YY, Hsu CY, Lin W (2000) Effects of fluid management on edema volume and midline shift in a rat model of ischemic stroke. Stroke 31:1702-1708. CrossRef Medline

Pascual MG, Alcácer VS, Pomares MV, Alberola MA (2011) BrownSéquard-plus syndrome after a stab injury. NeuroRehabilitation 29:353357. CrossRef Medline

Polderman KH, Varon J (2015) Interpreting the results of the targeted temperature management trial in cardiac arrest. Ther Hypothermia Temp Manag 5:73-76. CrossRef Medline

Rakers C, Schmid M, Petzold GC (2017) TRPV4 channels contribute to calcium transients in astrocytes and neurons during peri-infarct depolarizations in a stroke model. Glia 65:1550-1561. CrossRef Medline

Ritchie JM, Straub RW (1957) The hyperpolarization which follows activity in mammalian non-medullated fibres. J Physiol 136:80-97. CrossRef Medline

Rungta RL, Choi HB, Tyson JR, Malik A, Dissing-Olesen L, Lin PJ, Cain SM, Cullis PR, Snutch TP, MacVicar BA (2015) The cellular mechanisms of neuronal swelling underlying cytotoxic edema. Cell 161:610-621. CrossRef Medline

Ryskamp DA, Jo AO, Frye AM, Vazquez-Chona F, MacAulay N, Thoreson WB, Križaj D (2014) Swelling and eicosanoid metabolites differentially gate TRPV4 channels in retinal neurons and glia. J Neurosci 34:1568915700. CrossRef Medline

Salter MG, Fern R (2005) NMDA receptors are expressed in developing oligodendrocyte processes and mediate injury. Nature 438:1167-1171. CrossRef Medline

Schiff SJ, Somjen GG (1985) The effects of temperature on synaptic transmission in hippocampal tissue slices. Brain Res 345:279-284. CrossRef Medline

Schwab JM, Seid K, Schluesener HJ (2001) Traumatic brain injury induces prolonged accumulation of cyclooxygenase- 1 expressing microglia/brain macrophages in rats. J Neurotrauma 18:881-890. CrossRef Medline

Shen J, Xu G, Zhu R, Yuan J, Ishii Y, Hamashima T, Matsushima T, Yamamoto S, Takatsuru Y, Nabekura J, Sasahara M (2018) PDGFR- $\beta$ restores blood-brain barrier functions in a mouse model of focal cerebral ischemia. J Cereb Blood Flow Metab. Advance online publication. Retrieved Jan. 1, 2018. doi: 10.1177/0271678X18769515. CrossRef Medline

Shibasaki K (2016) TRPV4 ion channel as important cell sensors. J Anesth 30:1014-1019. CrossRef Medline

Shibasaki K, Suzuki M, Mizuno A, Tominaga M (2007) Effects of body temperature on neural activity in the hippocampus: regulation of resting membrane potentials by transient receptor potential vanilloid 4 . J Neurosci 27:1566-1575. CrossRef Medline

Shibasaki K, Ikenaka K, Tamalu F, Tominaga M, Ishizaki Y (2014) A novel subtype of astrocytes expressing TRPV4 (transient receptor potential vanilloid 4) regulates neuronal excitability via release of gliotransmitters. J Biol Chem 289:14470-14480. CrossRef Medline

Shibasaki K, Sugio S, Takao K, Yamanaka A, Miyakawa T, Tominaga M, Ishizaki Y (2015) TRPV4 activation at the physiological temperature is a critical determinant of neuronal excitability and behavior. Pflugers Arch 467:2495-2507. CrossRef Medline

Stokum JA, Gerzanich V, Simard JM (2016) Molecular pathophysiology of cerebral edema. J Cereb Blood Flow Metab 36:513-538. CrossRef Medline

Suzuki M, Mizuno A, Kodaira K, Imai M (2003) Impaired pressure sensation in mice lacking TRPV4. J Biol Chem 278:22664-22668. CrossRef Medline

Tait MJ, Saadoun S, Bell BA, Papadopoulos MC (2008) Water movements in the brain: role of aquaporins. Trends Neurosci 31:37-43. CrossRef Medline 
Takayama Y, Shibasaki K, Suzuki Y, Yamanaka A, Tominaga M (2014) Modulation of water efflux through functional interaction between TRPV4 and TMEM16A/anoctamin 1. FASEB J 28:2238-2248. CrossRef Medline

Thompson RJ, Zhou N, MacVicar BA (2006) Ischemia opens neuronal gap junction hemichannels. Science 312:924-927. CrossRef Medline

Tucker B, Aston J, Dines M, Caraman E, Yacyshyn M, McCarthy M, Olson JE (2017) Early brain edema is a predictor of in-hospital mortality in traumatic brain injury. J Emerg Med 53:18-29. CrossRef Medline

Vardjan N, Horvat A, Anderson JE, Yu D, Croom D, Zeng X, Lužnik Z, Kreft M, Teng YD, Kirov SA, Zorec R (2016) Adrenergic activation attenuates astrocyte swelling induced by hypotonicity and neurotrauma. Glia 64: 1034-1049. CrossRef Medline

Veenith TV, Carter EL, Geeraerts T, Grossac J, Newcombe VF, Outtrim J, Gee GS, Lupson V, Smith R, Aigbirhio FI, Fryer TD, Hong YT, Menon DK, Coles JP (2016) Pathophysiologic mechanisms of cerebral ischemia and diffusion hypoxia in traumatic brain injury. JAMA Neurol 73:542-550. CrossRef Medline

Wang Y, Moges H, Bharucha Y, Symes A (2007) Smad3 null mice display more rapid wound closure and reduced scar formation after a stab wound to the cerebral cortex. Exp Neurol 203:168-184. CrossRef Medline

White JP, Cibelli M, Urban L, Nilius B, McGeown JG, Nagy I (2016) TRPV4: molecular conductor of a diverse orchestra. Physiol Rev 96:911-973. CrossRef Medline 